\title{
STRATEGI PENGEMBANGAN KECERDASAN NATURALIS PADA ANAK USIA DINI
}

\author{
Aip Saripudin \\ Institut Agama Islam Negeri (IAIN) Syekh Nurjati Cirebon \\ Email: doubleaip82@gmail.com \\ Orcid ld: http://orcid.org/0000-0003-1815-9274
}

Article received: 11 March 2017 Review process: 15 March 2017

Article published: 30 March 2017

\begin{abstract}
Abstrak
Pendidikan anak usia dini merupakan pendidikan yang pertama dan utama untuk membentuk karakter anak lebih baik di masa yang akan datang. Diakui atau tidak, saat ini kualitas pendidikan indonesia masih rendah, padahal kualitas pendidikan sangat menentukan kualitas pembentukan sumber daya manusia yang potensial. Dalam konteks pembelajaran di PAUD, masih ditemukan pembelajaran yang konvensional dan terpusat pada guru (teacher centre). Guru lebih aktif daripada anak, sehingga anakanak tidak diberikan kesempatan untuk menumakan gagasan, konsep serta buah fikiran dengan sendirinya. Selain itu, pengenalan lingkungan baik di dalam kelas maupun diluar kelas belum diberikan secara maksimal, kalaupun ada sangat terbatas dengan metode yang sama. Masih ditemukannya Guru yang belum dapat memanfaatkan lingkungan sekitar, baik hewan, tumbuhan serta kejadian-kejadian alam yang ada di lingkungan sekitar sekolah untuk dijadikan sebagai bagian dari pembelajaran anak. Hal ini tentunya berakibat pada lemahnya anak dalam berpendapat, menemukan ide, berfikir kreatif, menemukan sesuatu, serta anak belum menunjukan bakat kecerdasan alamnya dengan baik. Untuk itu maka guru dapat mengembangkan keahliannya melalui berbagai upaya cerdas yang dapat mengembangkan kemampuan anak lebih berkembang melalui berbagai strategi dan pendekatan pembelajaran yang lebih baik.
\end{abstract}

Kata Kunci: Kecerdasan Naturalis, Anak Usia Dini

\section{A. PENDAHULUAN}

Memiliki jumlah penduduk dengan sumber daya yang berkualitas merupakan kebanggaan bagi suatu bangsa, sehingga mampu menopang pada berbagai sendi-sendi kehidupan berbangsa dan bernegara. Kondisi seperti ini tidak akan terjadi apabila anak-anak saat ini dibiarkan, ditelantarkan, dikekang, dikebiri dan tidak diberikan intervensi atas kemampuan dan kecerdasan yang mereka miliki saat ini. Berdasarkan konstitusi dikatakan bahwa pendidikan anak usia dini merupakan suatu upaya pembinaan yang ditujukan kepada anak sejak lahir sampai dengan usia enam tahun yang dilakukan melalui pemberian rangsangan pendidikan untuk membantu pertumbuhan dan perkembangan jasmani dan rohani agar memiliki kesiapan dalam memasuki pendidikan lebih lanjut (UU RI No 20 Tahun 2003). Untuk mewujudkannya, maka harus 
dipersiapkan pola pendidikan, pengasuhan dan pengembangan anak usia dini secara terencana, terpadu dan menyeluruh yang melibatkan semua komponen yang dapat mempengaruhi tumbuh dan berkembangnya anak usia dini. Komponen tersebut harus terlibat secara aktif dan penuh tanggungjawab, sehingga anak-anak dididik dan dilayani sesuai perkembangannya. Saat ini banyak lembaga swasta maupun secara perorangan mendirikan PAUD untuk melayani kebutuhan pendidikan anak usia dini di lingkungannya. Namun dalam faktanya sekolah tersebut banyak menyalahi aturan dan bahkan cenderung asal-asalan. Hal ini justru menjadi sangat berbahaya bagi perkembangan anak, sehingga anak tumbuh tidak sesuai dengan perkembangan yang seharusnya. Dapat dibayangkan bagaimana anak dapat menstimulasi perkembangan dan pertumbuhan kecerdasannya, apabila sarana dan prasarana yang ada tidak memadai dan bahkan tidak tersedia. Seperti halnya ruangan yang terlalu sempit, ruangan pengap karena pencahayaan yang kurang, tempat bermain anak terbatas, sarana dan prasarana tidak tersedia serta alat peraga edukatif masih minim.

Hal ini tentu bertolak belakang dengan prinsip perkembangan yang merupakan suatu proses yang bersifat kumulatif, artinya perkembangan terdahulu akan menjadi dasar perkembangan selanjutnya. Apabila perkembangan awal tidak ada hambatan, maka perkembangan selanjutnya akan baik, begitu pula sebaliknya (Martini Jamaris, 2010: 90). Oleh karena itu untuk tumbuh kembang anak diperlukan dukungan bukan hanya sekedar datang, masuk sekoah, kemudian pulang, namun harus ada dukungan dari orang tua, dukungan sarana dan prasarana pendidikan, lingkungan sekitar dan ketersediaan tenaga pendidik yang memadai. Peran serta semua komponen perlu ada dan mendukung terhadap tumbuh dan berkembangannya anak, bukan hanya sekedar orang tua dan pendidik, namun lingkungan sekitar (tetangga) juga berperan.

Masa kanak-kanak merupakan masa yang paling kaya, masa ini seyogyanya didayagunakan oleh pendidik sebaik mungkin. Tugas pendidik adalah memanfaatkan tahuntahun awal kanak-kanak dengan kepedulian yang tinggi bukan menyia-nyakannya (Martini Jamaris, 2010: 90). Hal inilah yang melatarbelakangi betapa pentingnya pengasuhan pada anak usia dini melalui penanganan yang tepat dan terencana, sehingga pengasuhan dan pendidikan pada anak usia dini dilakukan secara serius guna mewujudkan manusia yang berkualitas. Seorang anak yang dibesarkan dengan suasana keluarga terbuka, saling menghargai, saling menerima, dan mendengarkan pendapat anggota keluarganya, maka ia akan tumbuh menjadi generasi yang terbuka, fleksibel, penuh inisiatif, dan produktif, suka tantanga dan percaya diri 
(Yeni Rahmawati at all, 2010: 8). Sehingga seharusnya orangtua memahami hal tersebut untuk perkembangan anak selanjutnya. Beberapa kasus terjadi di masyarakat kita, bahwa anak dipaksa untuk memahami sesuat, melakukan sesuatu dengan tanpa melihat aspek perkembangannya. Hal ini justru akan merusak dan berdampak tidak baik bagi perkembangan dan kemampuan anak ke depan. Padahal kemampuan yang harus dimiliki oleh anak tidak diproleh secara lagsung, tetapi secara bertahap dan bergantung kepada banyaknya stimulus dan ruang gerak anak dalam mengeksplorasi lingkungan hidupnya sejak anak lahir (Ratih Zimer G, 2009: 103).

Namun pada kenyataannya masih banyak yang belum memperoleh perhatian yang baik, sehingga kepedulian anak terhadap lingkungan dan alam sekitar masih rendah. Contoh paling nyata dan ada di lingkungan sekitar kita adalah seringnya anak buang sampah sembarangan, diatas meja, di bawah bangku bahkan berserakan di dalam dan diluar ruangan kelas. Selain itu anak-anak tidak pernah belajar di luar kelas untuk sekedar mengamati pohon-pohon yang ada di sekeliling sekolah, sehingga pada saat anak diajak belajar di luar kelas, anak-anak belum bisa menyebutkan nama-nama tumbuhan yang mereka temui setiap hari. Hal-hal tersebut diatas merupakan bagian dari kecerdasan naturalis anak yang masih rendah dan perlu strategi untuk mengembangkannya.

\section{B. KAJIAN TEORETIK}

\section{Pendidikan Anak Usia Dini}

Definisi anak usia dini sampai saat ini menjadi perdebatan yang cukup panjang. Berdasarkan Undang-Undang, anak usia dini merupakan anak yang berada pada rentang usia 0-6 tahun (UU No 20 Tahun 2003). Ada yang mengatakan bahwa periode atau rentang anak usia dini dimulai dari 0-8 tahun. Perbedaan tersebut mempunyai alasan terutama dalam proses perkembangan kognitif anak usia dini yang mencapai tingkat percepatan $80 \%$ dari keseluruhan otak orang dewasa. Sedemikian pentingnya masa anak usia dini tersebut, sehingga para ahli mengatakan bahwa usia tersebut merupakan masa keemasan atau the golden age (Suyadi, 2010: 8). Dalam referensi lain dikatakan bahwa anak usia dini merupakan individu yang sedang mengalami proses pertumbuhan dan perkembangan yang sangat pesat, bahkan dikatakan sebagai lompatan perkembangan (H.E Mulayasa (2012: 16). Artinya bahwa perkembangan merupakan suatu proses yang dialami oleh setiap manuasia, tidak terkecuali anak-anak. Bahkan masa anakanak memiliki lompatan perkembangan yang sangat pesat dan berharga untuk kehidupan yang akan datang, sehingga diperlukan intervensi melalui program pendidikan anak usia dini yang 
dapat memberikan kemampuan yang lebih baik kepada anak. Berbagai cara dapat dilakukan dalam pendidikan anak usia dini seperti permainan, nyanyian, irama, dongeng, cerita, olahraga, sandiwara, role play, Bahasa, seni, agama serta lingkungan alam (Soegeng Santoso, 2011: 91).

Program pendidikan anak usia dini merupakan pendidikan yang menentukan terbentuknya kepribadian anak yang terjadi sejak anak dalam kandungan (secara tidak langsung), masa bayi hingga anak berumur kurang lebih 8 tahun. Pendidikan anak usia dini berada dalam proses pertumbuhan dan perkembangan yang bersifat unik, sehingga memiliki pola pertumbuhan dan perkembangan yang khusus sesuai dengan tingkat pertumbuhan dan perkembangannya. Menurut beberapa pandangan Maria Montesori (1870-1952) bahwa masa anak-anak merupakan masa peka yang ditandai oleh suatu keadaan dimana suatu potensi menunjukan kepekaan untuk berkembang, sehingga pendidikan harus segera memberikan arahan atau stimulasi yang berguna bagi anak (Soegeng Santoso, 2002: 9).

Upaya pembinaan yang ditujukan bagi anak usia 0-6 tahun tersebut dilakukan melalui Pendidikan anak usia dini (PAUD). Pendidikan anak usia dini dapat dilaksanakan melalui pendidikan formal, nonformal dan informal. Pendidikan anak usia dini jalur formal berbentuk taman kanak-kanak (TK) dan Raudatul Athfal (RA) dan bentuk lain yang sederajat. Pendidikan anak usia dini jalur nonformal berbentuk kelompok bermain (UU No 20 tahun 2003). Sedangkan prinsip utama pembelajaran PAUD adalah bermain sambil belajar yang sesuai dengan tingkat usia, perkembangan psikologis dan kebutuhan spesifik anak, serta yang mendekatkan anak dengan lingkungannya. Hal ini sejalan dengan prinsip utama PAUD yaitu memberikan stimulasi pendidikan kepada anak dalam rangka melejitkan semua potensinya agar anak memiliki kesiapan untuk mengikuti pendidikan lebih lanjut (Ace Suryadi, 2007: 89). Disamping itu pendidikan anak usia dini tentunya memiliki tujuan yaitu membangun landasan bagi berkembangnya potensi anak agar menjadi manusia beriman dan bertaqwa kepada Tuhan Yang Maha Esa, berahlak mulia,, sehat, berilmu, cakap, kritis, kreatif, inovatif, mandiri, percaya diri, dan menjadi warga Negara yang demokratis dan bertanggungjawab (Wayan A.S, 2010: 12).

\section{Perkembangan Kognitif Anak Usia Dini}

Dalam bukunya William Crain terjemahan Yudi Santoso (2007: 12), menurut Jean Piaget, terdapat empat tahapan perkembangan kognitif yaitu sebagai berikut: 
Tabel 1 Tahap Perkembangan Kognitif Anak Usia Dini

\begin{tabular}{|l|l|}
\hline \multicolumn{1}{|c|}{ Periode } & \multicolumn{1}{|c|}{ Perkembangan } \\
\hline Periode -1 & $\begin{array}{l}\text { Kepandaian sensori - motorik (dari lahir sampai 2 tahun). Bayi } \\
\text { mengorganisasikan skema tindakan fisik mereka seperti menghisap, } \\
\text { menggenggam dan memukul untuk menghadapi dunia yang muncul } \\
\text { dihadapannya }\end{array}$ \\
\hline Periode - II & $\begin{array}{l}\text { Pikiran pra operasional (2-7 tahun). Anak-anak belajar berfikir } \\
\text { menggunakan symbol-simbol dan pencitraan batiniah, namun pikiran } \\
\text { mereka masih tidak sistematis dan tidak logis. Pikiran di titik ini sangat } \\
\text { berbeda dengan pikiran orang dewasa }\end{array}$ \\
\hline Periode - III & $\begin{array}{l}\text { Operasi-operasi berfikir konkrit (7-11 tahun). Anak-anak } \\
\text { mengembangkan kemampuan berfikir sistematis namun hanya ketika } \\
\text { mereka dapat mengcu kepada objek-objek dan aktifitas-aktifitas konkret }\end{array}$ \\
\hline Periode - IV & $\begin{array}{l}\text { Operasional-operasional berfikir formal (11 tahun - dewasa). Orang } \\
\text { muda mengembangkan kemampuan untuk berfikir sistematis menurut } \\
\text { rancangan yang murni abstrak dan hipotesis }\end{array}$ \\
\hline
\end{tabular}

Dari table tersebut maka dapat ditarik kesimpulan bahwa usia 4-6 tahun merupakan usia yang berada dalam masa pra operasional, dimana anak-anak masih berfikir tidak sistematis serta tidak logis. Untuk mengetahui bagaimana capaian perkembangan kognitif anak usia dini, maka dapat dilihat dalam table berikut:

Tabel 2 Tabel Capaian Perkembangan Kognitif Pada Anak Usia Dini

\begin{tabular}{|c|c|c|}
\hline No & Anak Usia & Capaian Perkembangan Kognitif \\
\hline 1 & $\begin{array}{l}\text { Lahir } \quad-1 \\
\text { Tahun }\end{array}$ & $\begin{array}{l}\text { - } \text { Mengenal Benda } \\
\text { - } \text { Mengenal Bentuk }\end{array}$ \\
\hline 2 & 1-2 Tahun & $\begin{array}{l}\text { - } \text { Mengenal warna } \\
\text { - } \quad \text { Mengenal rasa: Manis, pahit, dan asam } \\
\text { - } \quad \text { Mengenal bilangan } 1 \text { dan } 2\end{array}$ \\
\hline 3 & 2-3 Tahun & $\begin{array}{l}\text { - Mampu mengelompokan benda yang berbentuk sama } \\
\text { - Mampu membedakan bentuk lingkaran dan bujur sangkar } \\
\text { - Mampu membedakan rasa dan warna }\end{array}$ \\
\hline
\end{tabular}




\begin{tabular}{|c|c|c|}
\hline & & - Mengenal bilangan hingga hitungan 5 \\
\hline 4 & 3-4 Tahun & $\begin{array}{l}\text { - } \text { Mampu membedakan bentuk bentuk dan ukuran (besar-kecil, } \\
\text { panjang- pendek, sedikit- banyak dll) } \\
\text { - Mampu mengurutkan angka satu sampai dengan } 10 \\
\text { - Mampu membeda-bedakan warna lebih banyak (merah, hijau, } \\
\text { hitam, putih, biru dan lain-lain) }\end{array}$ \\
\hline 5 & 4-5 Tahun & $\begin{array}{l}\text { - Menunjukan rasa ingin tahu cara kerja sesuatu } \\
\text { - Suka membongkar mainannya sendiri untuk sekedar dilihat } \\
\text { apa yang ada di dalamnya dan kemudian dirangkai lagi } \\
\text { - Suka mengurut-urutkan (membuat urtan) sesuatu dari yang } \\
\text { paling kecil agak besar hingga yang paling besar atau } \\
\text { sebaliknya }\end{array}$ \\
\hline 6 & 5-6 Tahun & $\begin{array}{l}\text { - Mampu mengurutkan bilangan } 1 \text { hingga minimal } 50 \\
\text { - Senang dengan permainan otak atik bilangan } \\
\text { - Menyukai permainan dalam computer } \\
\text { - Dengan mudah meletakkan benda sesuai } \\
\text { kelompoknya }\end{array}$ \\
\hline
\end{tabular}

\section{Kecerdasan Naturalis Anak Usia Dini}

Masa anak-anak merupakan masa dimana semua perkembangan baik kognitif maupun fisik berkembang secara cepat. Sekitar $80 \%$ anak dapat menunjukkan perkembangannya secara maksimal. Perkembangan Fisik merupakan perkembangan yang sangat cepat, dan orang tua dapat memberikan stimulasi yang lebih agresif pada anak, sehingga seluruh kemampuan fisik anak dapat berjalan optimal sesuai dengan perkembangannya. Perkembangan dapat dimaknai sebagai suatu gejala dimana kecerdasan anak akan mulai tampak, walaupun derajat kecerdasannya berbeda-beda. Kecerdasan adalah satu hal bahwa terdapat orang-orang pandai yang dapat diharapkan tampil dengan baik dalam berbagai jenis situasi pembelajaran (Robert E. Slavin, 2008: 163). Menurut Gardner, manusia memiliki semua kecerdasan, walau dengan derajat yang beragam. Masing-masing orang mungkin memiliki satu kecerdasan dominan dan kecerdasan sekunder yang digunakan dalam mencerap, mengingat dan penerapan pembelajaran (Agus Nggermanto, 2001: 208). 
Alfred Binet mengatakan bahwa kecerdasan merupakan kemampuan yang terdiri dari tiga komponen yaitu (1) kemampuan utuk mengarahkan pikiran atau tindakan, (2) kemampuan untuk mengubah arah pikiran atau tindakan, (3) kemampuan untuk mengkritisi pikiran dan tindakan diri sendiri (Tadkiroatun Musfiroh, 2008: 1.3). David Wechsler menyatakan bahwa intelegensi merupakan kemampuan untuk bertindak secara terarah, berfikir secara rasional dan menghadapi lingkungannya secara efektif. Lebih lanjut dikatakan bahwa kecerdasan merupakan suatu kekuatan mental yang dibawa oleh individu sejak lahir dan dapat dipergunakan untuk menyesuaikan diri di lingkungan yang baru, serta untuk memecahkan problem-problem yang dihadapi dengan cepat dan cepat (Asadi Muhammad, 2010: 33). Kecerdasan juga dapat dimaknai sebagai kemampuan untuk menyelesaikan masalah. Hal inilah yang menjadi dasar sehingga muncul istilah kemampuan intelegensi yang oleh Edward Lee Thorndike diklasifikasikan menjadi tiga yaitu (1) kemampuan abstraksi, (2) kemampuan mekanik serta (3) kemampuan sosial. Dari ketiga klasifikasi tersebut, maka akan memungkinkan berkorelasi satu sama lain dan juga memungkinkan tidak sangat berkorelasi satu sama lain. Ada anak yang menonjol dalam mekanik, sementara di sosial tidak, dan ada juga anak yang secara bersama-sama tiga kemampuan tersebut akan muncul.

Multiple Intelligences yang dalam bahasa Indonesia diterjemahkan sebagai kecerdasan majemuk atau kecerdasan ganda merupakan salah satu teori kecerdasan yang memperoleh banyak pengakuan akhir-akhir ini. Multiple intelegency adalah sebuah penilaian yang melihat secara deskriptif bagamana individu menggunakan kecerdasanya untuk memecahkan masalah dan menghasilkan sesuatu (Yuliani Nurani Sujiono, 2009: 183). Teori ini dicetuskan oleh Howard Gardner, psikolog dari Harvard yang telah menemukan 9 kecerdasan manusia. Asumsi MI muncul karena hasil penelitian Gardner yang memberikan gambaran bahwa individu dapat mencapai keberhasilan tidak hanya mengandalkan IQ tinggi namun juga didukung oleh kecerdasan yang dikembangkan oleh seseorang tersebut.

Tabel 3 Tabel Kecerdasan Jamak (Robert E. Slavin, 2008: 165)

\begin{tabular}{|l|l|l|}
\hline \multicolumn{1}{|c|}{ Kecerdasan } & \multicolumn{1}{|c|}{ Keadaan Akhir } & \multicolumn{1}{c|}{ Komponen Inti } \\
\hline Logika/Matemati & $\begin{array}{l}\text { Ilmuwan, ahli } \\
\text { katematika }\end{array}$ & $\begin{array}{l}\text { Kepekaan dan kemampuan memahami pola-pola } \\
\text { logis atau numeric, kemampuan menangani rantai } \\
\text { penalaran yang panjang }\end{array}$ \\
\hline Linguistik & Penyair, wartawan & \multicolumn{1}{|c|}{ Kepekaan terhadap bunyi, ritme, dan makna } \\
\hline
\end{tabular}




\begin{tabular}{|c|c|c|}
\hline & & $\begin{array}{l}\text { kata-kata, kepekaan terhadap fungsi Bahasa yang } \\
\text { berbeda }\end{array}$ \\
\hline Musik & $\begin{array}{l}\text { Penulis lagu, pemain } \\
\text { biola }\end{array}$ & $\begin{array}{l}\text { Kemampuan menghasilkan dan menghargai } \\
\text { ritme, rendah tingginya nada dan warna nada, } \\
\text { penghargaan pada bentuk-bentuk daya ekspresi } \\
\text { music }\end{array}$ \\
\hline Naturalis & $\begin{array}{l}\text { Ahli ilmu alam, ahli } \\
\text { botani, pemburu }\end{array}$ & $\begin{array}{l}\text { Kepekaan terhadap benda alam, seperti tanaman } \\
\text { dan binatang, membuat pembedaan indera yang } \\
\text { tajam }\end{array}$ \\
\hline Ruang & $\begin{array}{l}\text { Ahli navigasi, } \\
\text { pemahat }\end{array}$ & $\begin{array}{l}\text { Kemampuan memahami dunia visual-ruang } \\
\text { degan tepat dan melakukan transformasi terhadap } \\
\text { persepsi awal seseorang }\end{array}$ \\
\hline $\begin{array}{l}\text { Jasmani/Kinesteti } \\
\mathrm{k}\end{array}$ & Penari, atlet & $\begin{array}{l}\text { Kemampuan mengendalikan gerakan tubuh } \\
\text { seseorang dan menangani objek dengan terampil }\end{array}$ \\
\hline Antar-Pribadi & $\begin{array}{l}\text { Ahli } \\
\text { wiraniaga }\end{array}$ & $\begin{array}{l}\text { Kemampuan memahami dan menanggapi } \\
\text { dengan tepat suasana hati, temperamen, motivasi } \\
\text { dan keinginan orang-orang lain }\end{array}$ \\
\hline Intra-Pribadi & $\begin{array}{l}\text { Orang yang } \\
\text { mempunyai } \\
\text { pengetahuan diri } \\
\text { yang rinci dan tepat }\end{array}$ & $\begin{array}{l}\text { Akses ke perasaan perasaan diri sendiri } \\
\text { seseorang dan kemampuan membedakan sebagai } \\
\text { perasan tersebut dan memanfaatkannya untuk } \\
\text { menuntun pprilaku, pengetahuan tentang } \\
\text { kekuatan, kelemahan, keinginan dan kecerdasan } \\
\text { diri seseorang }\end{array}$ \\
\hline
\end{tabular}

Dari Sembilan aspek kecerdasan yang dikemukakan diatas, maka selayaknya guru harus mengoptimalkan pembelajaran kepada anak, walaupun tingkat kecerdasan anak pada akhirnya berbeda-beda, ada yang dominan da nada juga yang standar. Dengan mengoptimalkan multiple intelligences membuka peluang bagi setiap manusia untuk menjadi cerdas, kreatif dan jenius (Agus Nggermanto, 2001: 201). 


\section{PEMBAHASAN}

Periode anak usia dini merupakan periode emas dimana seluruh perkembangan perlu dioptimalkan. Stimulasi penting untuk diberikan agar anak semakin berkembang, rasa ingin tahunya semakin meningkat dan senantiasa mencari jawaban melalui eksplorasi, trial and error. Anak pada dasarnya tidak ada yang bodoh, semua anak memiliki kesempata yang sama untuk memiliki kecerdasan yang sama, namun kadar kecerdasannya yang sangat berbeda satu sama lain. Berdasarkan penelitian para ahli terbukti bahwa perkembangan kapasitas intelektual telah mencapai 50\% ketika anak berusia 4 tahun, 80\% setelah anak berusia 8 tahun, dan genap 100\% setelah anak berusia 18 tahun (Osborn, White dan Bloom) (Ace Suryadi, 2007: 96). Untuk itu masa golden age ini perlu mendapatkan perhatian yang optimal, sehingga perkembangan kecerdasan anak pun akan optimal.

Kecerdasan merupakan keterampilan berfikir dan kemampuan untuk beradaptasi dan belajar dari pengalaman hidup sehari-hari. Kecerdasan meliputi karakteristik seperti kreativitas dan keahlian interpersonal (John W, Santrock, 2002: 317). Sehingga dapat disimpulkan bahwa kecerdasan erat hubungannya dengan pengalaman hidup sehari hari, baik yang bersifat baik maupun yang bersifat buruk. Namun tentunya, kecerdasan atau kemampuan memiliki system nilai dan moral yang fositif, sehingga dapat dilihat dari berbagai aspek yang melingkupinya.

Untuk memahami kecerdasan naturalism maka Howard Gadner mengemukakan kecerdasan natularistik sebagai berikut:" a naturalist as a person who recognizes flora and fauna plus other consequential distinction in the natural world and uses this ability productively" (Reeta Sonawat \& Purvi Gogri, 2008: 85. Lalu kecerdasan naturalis diartikan sebagai The ability to discriminate among numerous species of flora and fauna, enjoyment of the natural world and ecological sensitivity (Jane Arnold Morgan and M Carmen Fonseca, 2004: 130. Pernyataan tersebut memiliki arti bahwa seseorang yang memiliki kecerdasan naturalistik ialah individu yang dapat mengenali flora dan fauna beserta hal lainnya yang ada di alam dan menggunakan kemampuannya secara produktif". Devinisi lain mengenai kecerdasan naturalis diungkapkan sebagai kemampuan mengobservasi pola-pola alam dan memahami system alamiah atau system buatan manusia (Reta Sonawat and Purvi Gogri, 2008: 323). Beberapa devinisi lain dikemukakan bahwa kecerdasan naturalis merupakan kemampuan untuk mengenali berbagai jenis flora (tanaman), fauna (hewan), dan fenomena alam lainnya. 
Thomas Armstrong mengemukakan bahwa kecerdasan naturalistik adalah:"expertise in the recognition and classification of the numerios species-the flora and fauna-of an individual's environment. This also includes sensitivity to other natural phenomena (e.g.,cloud formation, mountains, etc) and, in the case of thouse growing up in an urban environment, the capacity to discriminate among inanimate objects such as cars, snearkes, and CD covers" (Thomas Armstrong, 2009: 7). Selain itu kecerdasan naturalis dapat diartikan deal with classification abilities or flora and fauna of one's environments (Ahmed Gasem Alseed Ahmed, 20012: 28). Dari definisi tersebut, maka kecerdasan naturalis merupakan keahlian di dalam penggolongan dan pengenalan banyak spesies, tumbuh-tumbuhan dan fauna dalam lingkungan perorangan.

Kemudian kecerdasan naturalis dimaknai sebagai keahlian mengenali spesies (flora dan fauna) di lingkungan sekitar, mengenali eksistensi suatu spesies, memetakan hubungan antar spesies. Kecerdasan naturalis ialah kemampuan merasakan bentuk-bentuk serta menghubungkan elemen-elemen yang ada di alam (Yuliani Nurani Sujiono: 183). Kemudian fungsi dari kecerdasan naturalis akan tampak mencolok ketika mengamati tanaman, hewan serangga, dan benda alam yang berada di sekitar kita (Suyadi 178). Orang yang memiliki kecerdasan naturalis yang tinggi menyadari bagaimana membedakan tanaman, hewan, pegunungan, konfigurasi awan yang berbeda dalam ceruk ekologisnya (Howard Gadner, 2013: 33).

Beberapa hal yang dapat menjadi alasan bahwa kecerdasan naturalis ini perlu dikembangkan adalah bahwa dunia ini semakin tua, dan banyak sekali orang yang tidak peduli terhadap alam dan lingkungannya. Penebangan pohon, pembalakan hutan, pemburuan satwa langka serta jual beli hewan-hewan dilindungi. Sehingga pada akhirnya akan merusak ekosistem yang ada. Biasanya ini terjadi pada orang-orang yang rendah kecerdasan naturalisnya, sehingga sangat mudah merusak dan tidak ramah terhadap lingkungannya. Dengan demikian kecerdasan naturalis ini sangat dibutuhkan oleh setiap orang, sehingga melalui kecerdasan ini mampu menjaga dan memelihara dan selalu berdampingan dengan mahluk lainnya. Sementara Bowles mengemukakan bahwa komponen inti dari kecerdasan naturalistik adalah sebagai beikut: (1) Kepekaan terhadap alam (flora, fauna, formasi awan, gunung-gunung) (2) Keahlian dalam membedakan anggota suatu spesies (3) Mengenali eksisitensi spesies lain dan memetakan hubungan antara beberapa spesies, baik secara formal maupun informal (4) Memelihara alam dan bahkan menjadi bagian dari alam itu sendiri (5) Mengunjungi tempat-tempat yang banyak 
dihuni binatang (6) Mampu mengetahui hubungan antara lingkungan dan alam (Bowles. T, Australian Journal of Educational \& Developmental Psychology), Vol. 8)

Muhammad Yaumi mengungkapkan bahwa kecerdasan naturalistik sebagai keahlian mengenali dan mengategorikan spesies, baik flora maupun fauna, dilingkungan sekitar, dan kemampuannya mengolah dan memanfaatkan alam, serta melestarikan alam (Muhammad Yaumi, 2013: 21). Berkaitan dengan kecerdasan naturalis maka beberapa hal yang merupakan ciri atau tanda anak memiliki kecerdasan ini adalah anak dapat: (a) menganalisis persamaan dan perbedaan (b) menyukai tumbuhan dan hewan (c) mengklasifikasi flora dan fauna (d) mengoleksi flora dan fauna (e) menemukan pola dalam alam (f) mengidentifikasi pola dalam alam (g) melihat sesuatu dalam alam secara detil (h) meramal cuaca (i) menjaga lingkungan (j) mengenali berbagai spesies (k) memahami ketergantungan lingkungan (1) melatih dan menjinakkan hewan (Tadkiroatun Musfiroh: 1.19).

Selain beberapa ciri diatas, maka berikut ini dipaparkan beberapa ciri spesifik berdasarkan usia anak usia dini yang mempunyai kecerdasan naturalis tinggi:

Tabel 4 Ciri-Ciri Anak Usia Dini yang mempunyai kecerdasan Naturalis Tinggi

\begin{tabular}{|c|c|c|}
\hline No & Usia & Ciri-Ciri \\
\hline 1 & 0-1 Tahun & $\begin{array}{l}\text { - Tertarik bermain di alam bebas } \\
\text { - Senang melihat gambar pemandangan alam }\end{array}$ \\
\hline 2 & 1-2 Tahun & $\begin{array}{l}\text { - Senang mengamati dan berinteraksi sederhana dengan tanaman } \\
\text { terutama tanaman hias dan bunga) dan hewan peliharaan seperti } \\
\text { kucing } \\
\text { - Mengenali sifat tanaman dan hewan peliharaan }\end{array}$ \\
\hline 3 & 2-3 Tahun & $\begin{array}{l}\text { - Senang bermain dengan benda-benda alam, seperti menata batu } \\
\text { kerikil, membuat mobil-mobilan dari tanah liat, menggunakan } \\
\text { uang dari daun dan lain-lain } \\
\text { - Asyik mengamati gerak gerik binatang peliharaan seperti ikan } \\
\text { hias dalam akuarim, burung terbang, kucing meloncat, dan lain } \\
\text { sebagainya }\end{array}$ \\
\hline 4 & 3-4 Tahun & $\begin{array}{l}\text { - Mampu membedakan objek alam sesuai dengan karakteristiknya, } \\
\text { misalnya bisa membedakan batu dengan kerikil, kucing dengan }\end{array}$ \\
\hline
\end{tabular}




\begin{tabular}{|c|c|c|}
\hline & & $\begin{array}{l}\text { anjing, dan Bunga dengan tanaman pada umumnya } \\
\text { - Mampu mengenali karakteristik benda dan hewan peliharaan } \\
\text { secara lebih detail }\end{array}$ \\
\hline 5 & 4-5 Tahun & $\begin{array}{l}\text { - Suka bermain cocok tanam } \\
\text { - Senang memelihara hewan peliharaan }\end{array}$ \\
\hline 6 & 5-6 Tahun & $\begin{array}{l}\text { - Mampu memberi makan hewan peliharaan secara sederhana } \\
\text { - Mampu menyiram tanaman secukupnya } \\
\text { - Mampu berkreasi memperindah taman atau halaman }\end{array}$ \\
\hline
\end{tabular}

Anak yang cerdas dalam naturalis akan terlihat sebagai anak yang penyayang binatang dan tumbuhan serta peka terhadap alam. Hal tersebut dapat dilihat melalui (1) kesenangan mereka terhadap tumbuhan, bunga-bungaan dan kecenderungan untuk merawat tanaman (2) sikap mereka yang sayang terhadap hewan piaraan (membelai, memberi makan-minum, mengoleksi binatang atau gambar miniaturnya (3) kemampuan mereka dalam mengenal dan menghafal nama-nama atau jenis binatang dan tumbuhan (4) kesukaan anak melihat gambar binatang atau hewan serta sering mengajukan pertanyaan-pertanyaan tentangnya (5) kepekaan terhadap bentuk, tekstur dan ciri lain atau unsur alam seperti bunga bungaan, awan dan bebatuan (6) kesenangan terhadap alam, menyukai kegiatan di alam terbuka seperti pantai, tanah lapang, kebun, sungai, sawah dan alam terbatas menghabiskan waktu di dekat kolam atau dekat aquarium ( Tadkiroatun Musfiroh, 1.19).

Dari penjelasan ditas maka dapat kita perhatikan bersama bahwa anak yang cenderung tidak geli memegang hewan piaraan, suka melihat hewan berlama-lama serta ekspresi terbuka dengan hewan yang dilihatnya menandakan bahwa anak tersebut memiliki kecerdasan naturalis yang tinggi. Begitu pula dengan anak-anak yang menyukai alam terbuka, memegang perkakas kebun atau sawah dan ingin mencobanya, maka dapat dikatakan anak tersebut juga memiliki kecerdasan naturalis yang tinggi. Jika anak didalam runangan menemukan bacaan tentang alam dan hewan serta menonton pertunjukan binatang atau TV yang menunjukan binatang dan alam terbuka, dia agresif dan berekspresi serta menunjukan kesukaan sehingga berlama-lama untuk nonton di depan TV atau DVD, hal ini uga menunjukan bahwa anak tersebut cenderung memiliki kecerdasan naturalis yang tinggi. 
Kecerdasan naturalis dapat dirangsang melalui berbagai hal misalnya melalui pengenalan sains secara verbal, penyediaan buku-buku sains, VCD hewan/tumbuhan, kegiatan bercocok tanam, menyiram bunga, memeilihara unggas, mengoleksi toys animal, mengoleksi benda-benda alam yang ada disekirtarnya misalnya batu-batuan, pasir, kacang-kacangan serta hal-hal lain yang sifanya berasal dari alam. Menurut Amstrong (2003) bahwa komponen kecerdasan naturalis adalah kepekaan terhadap alam, keahlian membedakan anggota-anggota suatu spesies, mengenali eksistensi spesies lain dan memetakan hubungan Antara beberapa spesies baik secara formal atau informal.

Amstrong dalam bukunya mengatakan Indikator kecerdasan naturalis pada anak usia dini meliputi: (1) Talks a lot about favorite pets, or preferred spots in nature, during class sharing (2) Likes field trips in nature, to the zoo, or to a natural history museum (3) Shows sensitivity to natural formations (e.g. while walking outside with the class, will notice mountains, clouds; or if in an urban environment, may show this ability in sensitivity to popular culture "formations" such as sneakers or automobile styles) (4) Likes to water and tend to the plants in the classroom (5) Likes to hang around the gerbil cage, the aquarium, or the terrarium in class (6) Gets excited when studying about ecology, nature, plants, or animals (7) Speaks out in class for the rights of animals or the preservation of planet earth (8) Enjoys doing nature projects, such as bird watching, collecting butterflies or insects, studying trees or raising animals (9) Brings to school bugs, flowers, leaves, or other natural things to share with classmates or teachers (10) Does well in topics at school that involve living systems (e.g. biological topics in science, environmental issues in social studies) (Thomas Amstrong, 38).

Kutipan diatas secara singkat dapat dijelaskan sebagai berikut: (1) Senang berbicara tentang hewan peliharaan favoritnya atau tempat yang disukai di alam (2) Suka kunjungan lapangan di alam, ke kebun binatang, atau ke museum sejarah alam (3) Menunjukkan kepekaan terhadap gejala alam (misalnya sambil berjalan di luar kelas sembari melihat gunung-gunung, awan, cenderung menyukai air dan tanaman di kelas (4) Suka berada di sekitar kandang gerbil (semacam hamster), akuarium. Bersemangat ketika belajar tentang ekologi, alam, tanaman, atau hewan (5) Berbicara di kelas untuk hak-hak binatang atau pelestarian planet bumi (6) Suka melakukan proyek alam, seperti mengamati burung, kupu-kupu atau serangga (7) Membawa binatang kecil ke sekolah, bunga, daun, atau hal-hal alam di kelas (8) Tertarik pada topik yang melibatkan sistem kehidupan (misalnya topik biologi dalam ilmu pengetahuan, isu-isu lingkungan dalam studi sosial). 
Selain itu terdapat indikator kecerdasan naturalis anak usia dini sebagai berikut:

a) Anak lebih banyak diluar kelas dari pada di dalam kelas, anak senang mendekat ke jendela dan melihat keluar (Usia 2-6 tahun) dan melaporkan kepada pendidik apa yang mereka lihat di luar jendela

b) Anak laki-laki tertarik pada gerombolan binatang kecil seperti semut. Binatang diikuti hingga menemukan sarang. Anak sengaja mencari binatang seperti cacing, ulat daun pisang bahkan berani ke sungai mencari ikan dan ke sawah mencari belut

c) Anak gemar mengumpulkan mini toys binatang, menikmati latihan mengoleksi daun dan bunga kamboja

d) Anak tertarik melihat majalah yang bergambar binatang dan tumbuhan, dan berkali-kali mengamatinya, banyak mempertanyakan gambar-gambar binatang.

e) Anak memiliki kesenangan dan cenderung hobi terhadap binatang seperti ikan, memelihara ikan di akuarium memegang dan memelihara ikan di toples serta memperhatikan gerakgerak ikan

f) Anak tampak senag berada di taman, tidak merusak tumbuhan yang ada di dalamnya bertanya tentang nama-nama bunga.

g) Anak-anak bercita-cita menjadi tukang kebun, penjual bunga, penakluk hewan liar, pendaki gunung, peselancar dan astronot

h) Anak tertarik mengamati gejala alam, seperti hujan, gunung berapi, angin, pohon yang basah dan tumbang, awan, atau banjir. Anak memperhatikan pemberitaan gejala alam yang ada di televise tentang banjir, longsor, gempa dan gunung meletus

i) Anak tidak takut terhadap binatang, seperti ulat, tidak mudah jijik terhadap binatang seperti cacing dan kecoak, berani mendekati anak kucing dan tidak menangis ketika kucing bereaksi secara agak agresif

j) Anak memilih berlibur ke kebun binatang, gunung, pantai atau desa.

Dari indikator yang dijelaskan diatas, maka dapat disimpulkan bahwa untuk memprediksi bahwa anak memiliki kecerdasan naturalis dapat dilihat dari kesukaan dan kecintaan anak terhadap alam, hewan dan tumbuhan. Tidak hanya sebatas menyenangi dan menyukai, namun lebih kepada gembira dan senang yang dituangkan dalam bentuk keinginan mengkoleksi dan keinginan untuk memiliki seusaitu dari alam, binatang serta tumbuhan. 
Kecerdasan naturalis pada anak usia dini dapat dikembangkan melalui berbagai cara. Adapun strategi yang dilakukan adalah sebagai berikut:

1. Mencari batu-batu unik, misalnya mencari jenis batu tertentu dengan ciri batu yang berbedabeda dari batu yang halus, kecil, berwarna putih atau hitam, batu yang tajam, batu yang besar.

2. Bereksperimen dengan rumput yaitu dengan cara menyediakan selembar kain/sisa bekas, potong berbentuk huruf atau angka. Kain tersebut di letakkan dihalaman yang di tumbuhi rumput, selanjutnya kain ditusukkan ke rumput dengan menggunakan tusukan gigi supaya tidak bergerak. Setelah satu minggu anak diajak melihat potongan kain tersebut dan apa yang terjadi, yaitu tampak gambar yang sama dengan pola potongan kain. Permainan ini di sebut proses fotosintesis. Rumput yang ditutupi potongan kain tidak mendapat cukup matahari sehingga tidak bisa berfotosintesis, tidak bisa mengolah makanan, sehingga daunnya berwarna hijau muda(kuning karena layu), seharusnya berwarna hijau tua.

3. Pergi ke museum yang berkaitan dengan alam, seperti ke museum geologi, museum ilmu pengetahuan alam dan sebagainya. Untuk mendapatkan informasi tentang kondisi alam, jenis binatang, ragam tumbuhan di masa lalu. Anak bisa mengetahui anatomi tubuh manusia maupun binatang, proses-proese biologi dan sebagainya. Aktivitas ini akan mengasah daya kritisnya terhadap masalah lingkungan.

4. Bereksperimen dengan bunga yaitu dengan cara menyediakan empat batang bunga sedap malam, atau bunga lain yang berwarna putih dan batangnya mempunyai pori-pori besar. Masukkan batang bunga tersebut ke dalam gelas yang sudah berisi air yang berwarna kuning, merah dan biru, serta satu gelas yang berwarna putih. Diamkan semalam, dan lihat keesokan harinya, anak pasti terkejut karena tiga batang bunga yang semula berwarna putih brubah berwarna kuning, merah dan biru, dan satu yang tetap berwarna puith. Melalui permainan ini, memberikan pengalaman kepada anak proses tumbuhan menyerap air.

5. Menanam bunga yaitu mengajak anak menanam bunga, sayur atau buah, dengan tanaman yang aman untuk anak yaitu yang tidak berduri, tidak berbulu, tidak berdaun kasar, tidakmengandung racun dan sebagainya. Pilih tanaman yang cepat berbunga atau berbuah, misalnya menanam tomat, strawberry, ketimun, wortel, aneka bunga, dan sebagainya. Dalam proses menanam, ajak anak untuk mengukur tinggi tanaman, menghitung jumlah daun, menghitung jumlah bunga, dan sebagainya. Aktivitas ini memberikan pemahaman 
mengenai berhitung, dan cara mengukur tinggi, yang meningkatkan kecerdasan logismatematisnya. Mengembangkan motorik kasarnya, melatih kesabaran serta tanggung jawab.

6. Pelihara binatang yaitu dengan memelihara binatang yang mudah perawatannya dan tidak membahayakan anak, contohnya kelinci, ikan, hamster, kura-kura dan sebagainya. Ajak anak untuk memberi makan binatang dan saat memberikan kandang / kolam. Bila anak sudah bisa memberikan makan binatang peliharaannya secara mandiri, bantu anak untuk membuat jadwal memberi makan binatang, dan berlatih untuk mematuhi jadwal tersebut. Aktivitas ini akan mengasah empati anak terhadap binatang serta melatihnya tanggung jawab.

\section{PENUTUP}

Perkembangan anak usia dini merupakan proses yang dialami individu secara alamaiah. Proses alamiah akan berkembang dengan baik apabila stimuasi yang diberikan tepat dan sesuai dengan perkembngan. Perkembangan terjadi sepanjang hidup manusia bahkan perkembangan yang paling cepat adalah perkembangan dimasa kanak-kanak. Perkembangan masa anak-anak memiliki lompatan perkembangan yang sangat pesat dan berharga untuk kehidupan yang akan datang, sehingga diperlukan intervensi melalui program pendidikan anak usia dini yang dapat memberikan kemampuan yang lebih baik kepada anak. Berbagai cara dan strategi dapat dilakukan dalam pendidikan anak usia dini seperti permainan, bernyanyi, berirama, dongeng, cerita, olahraga, sandiwara, Bahasa, agama serta lingkungan alam. Untuk merangsang kecerdasan naturalis anak usia dini, maka diperlukan berbagai strategi yang ditempuh sehingga perkembangan tersebut dapat optimal.

Pada dasarnya setiap manusia memiliki kecerdasan sama namun kadar kecerdasan tersebut yang berbeda-beda sehingga diperlukan pendampingan dari guru yang lebih baik. Proses-proses bimbingan menuju perkembangan naturalis yang tinggi dapat diperoleh dari guru, orang tua, serta masyarakat. Hal ini untuk mendorong agar anak lebih peka dan sayang terhadap lingkungan sekitarnya.

\section{DAFTAR PUSTAKA}

Armstrong, Thomas (2009). Multiple Intelligences in The Classroom. Virginia: ASCD Member Book.

Bowles. T, Self-rated Estimated of Multiple Intelligences Based on Aproaches to Learning (Australian Journal of Educational \& Developmental Psychology), Vol. 8. 
Crain, William. (2007). Terjemahan Yudi Santoso. Teori Perkembangan, Konsep dan Aplikasi. Yogyakarta: Pustaka Pelajar.

Gasem, Ahmed Alseed Ahmed. (2012). The Relation between Multiple Intellegences Theory and Methode of ELT (International Journal Learning and Teaching: Academic World Education and Research Centre.

Gadner, Howard. (2013). multiple Intelligences (Memaksimallkan Potensi \& Kecerdasan Individu dari Masa Kanak-Kanak Hingga Dewasa) Terjemahan Yelvi Andri Zaimur. Jakarta: Darras Books.

Gandasetiawan, Ratih Zimmer. (2009). Mengoptimalkan IQ dan EQ Anak Melalui Metode Sensomotorik. Jakarta: Libri.

Jamaris, Martini. (2010). Orientasi Baru Dalam Psikologi Pendidikan. Jakarta: Alfabeta.

Morgan, Jane Arnold and M Carmen Fonseca. (2004). Multiple Intelligence Theory and Foreign Language Learning: A Brain-based Perspective. University Of Murcia, International Journal of English Studies IJES.

Mulyasa, H.E. (2012). Manajemen PAUD. Bandung: Remaja Rosda Karya.

Musfiroh, Tadkiroatun. (2008). Pengembangan Kecerdasan Majemuk, Modul I. Jakarta: Universitas Terbuka.

Muhammad, Asadi. (2010). Deteksi Bakat dan Minat Anak Sejak Dini. Yogyakarta: Gara ilmu.

Nggermanto, Agus. (2001). Quantum Quetient (Kecerdasan Quantum, Cara Praktis Melejitkan IQ, EQ dan SQ yang Harmonis). Bandung: Nuansa.

Rachmawati, Yeni dan Euis Kurniati. (2010). Strategi Pengembangan Kreatifitas Pada Anak Usia Taman Kanak-Kanak. Jakarta: Kencana.

Slavin, Robert E. (2008). Psikologi Pendidikan (Teori dan Praktek Edisi Kedelapan. (Terjemahan). Jakarta: Indeks.

Suyadi. (2010). Psikologi Belajar PAUD Pendidikan Anak Usia Dini. Yogyakarta: Pedagogia.

Santoso, Soegeng. (2011). Konsep Pendidikan Anak Usia Dini Menurut Pendirinya. Jakarta: Citra Pendidikan.

Santoso, Soegeng. (2012). Pendidikan Anak Usia Dini. Jakarta: Citra Pendidikan. 
Suryadi, Ace. (2007). Mewujudkan Masyarakat Pembelajar (Konsep, Kebijakan dan Implementasi). Jakarta: Direktorat Jenderal Pendidikan Non Formal dan Informal Departemen Pendidikan Nasional.

Santrock, John W. (2002). Perkembangan Anak (Terjemahan Edisi Kesebelas Jilid I). Jakarta: Erlangga.

Sonawat, Reeta \& Purvi Gogri. (2008). Multiple Intillegence for Presschool Children. Mumbai: Multi-Tech Publishing co, fist edition.

Undang-Undang RI No 20 Tahun 2003 tentang Sistem Pendidikan Nasional

Wayan, I A.S (2010). Konsep dan Pedoman Pengembangan Kurikulum dan Program (Kurikulum Tingkat Satuan Pendidikan) Taman Kanak-Kanak/Raudhatul Athfal. Jakarta: Azzahra Books 8.

Yaumi, Muhammad. (2013). Pembelajaran Berbasis Kecerdasan Jamak Mengidentifikasi dan Mengembangkan Multitalenta Anak. Jakarta: Kencana Prenadamedia Group, edisi pertama. 